\title{
HALOSULFURON FOR SELECTIVE CONTROL OF PURPLE NUTSEDGE IN MAIZE
}

\author{
A. RAHMAN ${ }^{1}$, T.K. JAMES ${ }^{1}$, P. SANDERS ${ }^{2}$ and M. LANE ${ }^{3}$ \\ ${ }^{1}$ AgResearch, Ruakura Research Centre, P.B. 3123, Hamilton \\ ${ }^{2}$ Newell Road, $R$ D 3 Hamilton \\ ${ }^{3}$ Monsanto NZ Ltd, P O Box 390, Cambridge
}

\begin{abstract}
Ten field trials were conducted in the Waikato and Bay of Plenty between 1995 and 1997 to evaluate the effectiveness of post-emergence halosulfuron for control of purple nutsedge (Cyperus rotundus) in maize. Halosulfuron severely damaged the foliage of purple nutsedge and reduced its population and ground cover at rates between 32.5 and $130 \mathrm{~g} / \mathrm{ha}$. Repeat annual applications of halosulfuron were necessary to reduce the number of tubers to low levels. Halosulfuron caused chlorosis and some stunting of young maize plants but they grew out of the damage and neither grain yields nor crop maturity were affected. Crop tolerance was similar following prior use of any of the currently registered pre-emergence herbicides for maize.
\end{abstract}

Keywords: purple nutsedge, Cyperus rotundus, maize, halosulfuron, chemical control.

\section{INTRODUCTION}

First recorded in New Zealand by Cheeseman in 1883 (Allan 1940), purple nutsedge (Cyperus rotundus) is now distributed throughout most of the North Island from Northland to Wellington and also Nelson and Motueka (Healy and Edgar 1980). In recent years it has spread into arable lands of the Bay of Plenty, Waikato and Hawkes Bay, particularly affecting many maize and some asparagus crops. As seeds of purple nutsedge are rarely viable, its spread is associated with the movement of tubers and appears to have been aided by the increased use of contract growing of field crops with cultivation equipment travelling from site to site. Purple nutsedge is capable of producing tubers three weeks after shoot emergence (Hauser 1962) and a plant originating from one tuber can produce 99 tubers within three months (Rao 1968). Purple nutsedge has been described as the world's worst weed due to its extensive distribution and ability to compete vigorously in all crops resulting in large losses of yield (Holm et al. 1977; Santos et al. 1997).

Several selective and non-selective herbicides have been used overseas with varying success for control of purple nutsedge (e.g. Hawton et al. 1992; Webster and Coble 1997). Field trials by Sanders and Rahman (1995) in asparagus showed only limited long term activity of most residual herbicides. The recently released sulfonylurea herbicide, halosulfuron (NC-319; MON 12037), has shown good activity against purple nutsedge following soil and/or foliar applications (Suzuki et al. 1991; Vencill et al. 1995). The product was registered in 1994 in Australia for use on turf and in the USA for use on maize, sorghum and turf. The objective of this study was to determine the efficacy of halosulfuron, in combination with other selective herbicides, for the control of purple nutsedge and the tolerance of maize crops to this herbicide.

\section{MATERIALS AND METHODS}

Ten field trials were conducted in maize crops in the Waikato and Bay of Plenty over two growing seasons (1995-97) to evaluate various aspects of halosulfuron for control of purple nutsedge. Two trials in each growing season tested the tolerance of maize to halosulfuron in the absence of purple nutsedge. Two further trials in each 
season investigated its efficacy against the weed. Additionally two trials in 1996/97 evaluated the efficacy of repeat applications of halosulfuron.

All trials were randomised block designs with individual plots of 6-10 $\mathrm{m}$ x 3-6 m, containing four or eight crop rows, with treatments replicated 4 or 6 times. All herbicide treatments were applied with a $\mathrm{CO}_{2}$ powered precision sprayer in 300 litres/ ha water at $210 \mathrm{kPa}$. In the efficacy trials, a pre-emergence application of alachlor (Lasso Microtech) or acetochlor (Roustabout) plus atrazine (Gesaprim) was applied to each trial area by the grower.

\section{Efficacy trials}

The efficacy trials in both years were located at the same sites in Matamata and Te Teko (Bay of Plenty) which had been in maize previously and were infested with purple nutsedge. The soils were all sandy loams with high organic carbon contents (5.9 to $7.4 \%$ ) and $\mathrm{pH}$ levels between 5.6 and 6.1. The Matamata trials were planted in early November and the Te Teko trials in mid October in both seasons with maize cv. Pioneer 3751 (Pioneer 3730 at Te Teko in 1996). Pre-emergence applications of acetochlor + atrazine were made within 2 days of planting. The post-emergence treatments of halosulfuron (Sempra) with Citowett at $120 \mathrm{ml} / 100$ litres, were applied about 5 weeks and 6 weeks after planting in 1995 and 1996 respectively. At this time maize plants were $25-40 \mathrm{~cm}$ tall with 6-9 leaves, while the purple nutsedge plants were 5-10 cm high with 4-8 leaves. In the 1996/97 season, each location had two trials: one where the same herbicide treatments were repeated on the 1995/96 trial plots and the other on new ground adjacent to the old trial site, to again assess the effectiveness of a single application of halosulfuron.

Visual assessments of the phytotoxic damage to the weed were made at regular intervals on all trials. Purple nutsedge plant populations were determined on several occasions by counting in two to five randomly placed $0.1 \mathrm{~m}^{2}$ quadrats in each plot (depending on the density of infestation). After the nutsedge foliage had died back at the end of the season, two soil samples were collected from each plot to a depth of 300 $\mathrm{mm}$ using a $75 \mathrm{~mm}$ diameter corer. The numbers and dry weight of tubers were measured from the washed samples.

\section{Crop tolerance trials}

The tolerance trials in both years were located near Gordonton and Rukuhia in the Waikato, but on new sites in each year. All sites had been in maize for several years. The Gordonton sites had a peaty loam soil (16.2\% organic $\mathrm{C}, \mathrm{pH} 6.0)$ while the Rukuhia sites had a sandy loam soil (7.3\% organic C, pH 5.7). Maize cv. Pioneer 3514 (Pioneer 3527 in the Rukuhia trials) was planted in late October in both years. The preemergence treatments were applied within 3-4 days after planting. In addition to acetochlor, several other products were evaluated in the 1996/97 Rukuhia trial to assess whether the choice of the pre-emergence herbicide influenced the tolerance of maize to halosulfuron. These were alachlor, dimethanamid (Frontier), pendimethalin (Stomp), all tank mixed with atrazine, and metolachlor/terbuthylazine (Primextra II).

Regular visual assessments were made of any phytotoxic damage to the maize crop and plant height was determined on at least two occasions by measuring 10 plants/ plot. Maize grain yields were determined for all the trials by harvesting 100 plants from central rows of each plot. The cobs were then shelled, weighed and the moisture content of the grain measured. Grain yields were adjusted to $14 \%$ moisture content.

All data were subjected to analysis of variance (ANOVA) and least significant difference (LSD) test was used to compare treatments. Stabilising transformations were performed where necessary prior to analysis.

\section{Efficacy trials}

\section{RESULTS AND DISCUSSION}

Data from the two efficacy trials in the 1996/97 growing season (one trial where halosulfuron was applied for the first time and the second trial where repeat applications of the same treatments were made to the plots treated in 1995/96) at Matamata are presented in Table 1. Similarly the data from the two Te Teko trials are given in Table 2. The efficacy of halosulfuron treatments in the 1995/96 trials was comparable to the 
single application trials in 1996/97 at both sites and these data are not presented here. The one obvious exception in the first year trials was that the 65 and $130 \mathrm{~g} / \mathrm{ha}$ rates of halosulfuron provided consistently improved levels of control compared to the 32.5 $\mathrm{g} / \mathrm{ha}$ rate at the Matamata site.

TABLE 1: Plant and tuber numbers and vigour scores of purple nutsedge from the efficacy trials in maize at Matamata.

\begin{tabular}{|c|c|c|c|c|c|c|c|}
\hline \multicolumn{4}{|l|}{$\begin{array}{l}\text { Herbicide }(\mathrm{g} / \mathrm{ha}) \\
\text { (halosulfuron 16.12.96) }\end{array}$} & \multicolumn{2}{|c|}{ Vigour score ${ }^{\mathrm{b}}$} & \multicolumn{2}{|c|}{$\begin{array}{l}\text { Tubers } \\
5.5 .97\end{array}$} \\
\hline & 16.12 .96 & 24.2 .97 & 30.4 .97 & 7.1 .97 & 30.4 .97 & No. $/ \mathrm{m}^{2}$ & $\mathrm{M} \mathrm{g} / \mathrm{m}^{2}$ \\
\hline \multicolumn{8}{|c|}{ 1996/97 Trial (first application) } \\
\hline acetochlor + atrazine $^{\mathrm{a}}$ & 366 & 871 & 387 & 0.2 & 0.6 & 2527 & 331 \\
\hline+ halosulfuron 32.5 & 349 & 349 & 156 & 1.7 & 2.0 & 1320 & 191 \\
\hline+ halosulfuron 65 & 301 & 212 & 172 & 2.2 & 3.0 & 1320 & 186 \\
\hline + halosulfuron 130 & 392 & 177 & 125 & 2.5 & 2.9 & 1403 & 206 \\
\hline $\operatorname{LSD}(5 \%)$ & 107 & 84 & 118 & 0.6 & 0.7 & 714 & 111 \\
\hline \multicolumn{8}{|c|}{ 1996/97 Trial (Repeat application on $95 / 96$ plots) } \\
\hline acetochlor + atrazine $^{\mathrm{a}}$ & 270 & 643 & 104 & 0.3 & 0.4 & 2545 & 379 \\
\hline+ halosulfuron 32.5 & 108 & 79 & 42 & 2.0 & 2.3 & 764 & 80 \\
\hline+ halosulfuron 65 & 79 & 47 & 35 & 2.6 & 3.3 & 764 & 67 \\
\hline + halosulfuron 130 & 79 & 27 & 27 & 2.6 & 3.5 & 453 & 38 \\
\hline $\operatorname{LSD}(5 \%)$ & 64 & 69 & 47 & 0.8 & 0.6 & 470 & 66 \\
\hline
\end{tabular}

${ }^{\text {a }}$ Pre-emergence acetochlor + atrazine $(2.5+1.5 \mathrm{~kg}$ ai/ha) were applied to every plot in the trial.

${ }^{\mathrm{b}}$ On a $0-5$ scale: $0=$ No damage, full vigour, healthy; $5.0=$ All foliage showing damage symptoms.

TABLE 2: Plant and tuber numbers and vigour scores of purple nutsedge from the efficacy trials in maize at Te Teko.

\begin{tabular}{|c|c|c|c|c|c|}
\hline \multirow{2}{*}{$\begin{array}{l}\text { Herbicide (g/ha) } \\
\text { (halosulfuron 12.11.96) }\end{array}$} & \multicolumn{3}{|c|}{ No. of plants $/ \mathrm{m}^{2}$} & \multicolumn{2}{|c|}{ Vigour score $^{\mathrm{b}}$} \\
\hline & 12.11 .96 & 14.1.97 & 24.2 .97 & 19.12 .96 & 24.2 .97 \\
\hline \multicolumn{6}{|c|}{ 1996/97 Trial (First application) } \\
\hline acetochlor + atrazine ${ }^{\mathrm{a}}$ & 21 & 157 & 89 & 0 & 0.2 \\
\hline + halosulfuron 32.5 & 30 & 60 & 45 & 1.2 & 1.5 \\
\hline + halosulfuron 65 & 25 & 10 & 24 & 2.0 & 2.2 \\
\hline + halosulfuron 130 & 24 & 16 & 11 & 1.9 & 2.2 \\
\hline $\operatorname{LSD}(5 \%)$ & 13 & 27 & 23 & 0.8 & 0.8 \\
\hline \multicolumn{6}{|c|}{ 1996/97 Trial (Repeat application on $95 / 96$ plots) } \\
\hline acetochlor + atrazine ${ }^{\mathrm{a}}$ & 26 & 202 & 135 & 0.2 & 0.4 \\
\hline + halosulfuron 32.5 & 17 & 19 & 30 & 1.9 & 2.0 \\
\hline + halosulfuron 65 & 12 & 19 & 10 & 3.3 & 3.0 \\
\hline + halosulfuron 130 & 10 & 5 & 14 & 3.9 & 3.2 \\
\hline $\operatorname{LSD}(5 \%)$ & 6 & 13 & 27 & 0.9 & 0.6 \\
\hline
\end{tabular}

${ }^{\text {a }}$ Pre-emergence acetochlor + atrazine $(2.5+1.5 \mathrm{~kg}$ ai/ha $)$ were applied to every plot in the trial.

${ }^{\mathrm{b}}$ On a $0-5$ scale: $0=$ No damage, full vigour, healthy; $5.0=$ All foliage showing damage symptoms. 
Counts of nutsedge plants present when the halosulfuron treatments were applied (16.12.96 and 12.11.96 in Tables 1 and 2 respectively) show that in the trial area receiving treatments for the first time, there was a reasonably even spread of plants over all plots but in the trial receiving repeat treatments there was a carry-over effect from the previous year's application of halosulfuron. The largest reduction in plant numbers as a result of the carry-over effect was between the base treatment (acetochlor + atrazine) and any halosulfuron treatment, with smaller reductions in plant numbers occurring with increasing rates.

Within a week of treatment with halosulfuron, a gradual yellowing of the foliage of purple nutsedge was evident and this effect was assessed through the vigour scores (Tables 1 and 2). These indicated that new growth on the treated plants turned chlorotic, but the old leaves remained green for several weeks. The plants did not increase much in size and most withered eventually. Increasing levels of shading from the maize crop also appeared to assist in limiting the weed growth as the phytotoxic effects of the herbicide disappeared.

All halosulfuron treatments caused a large and significant reduction in nutsedge populations for the duration of the season. This is reflected in lower plant counts and lower tuber numbers (Tables 1 and 2). However, this reduction was greater in the trials with repeat treatments where the use of halosulfuron over two seasons had an additive effect, especially at the Matamata site (Table 1) where the initial weed population was higher. This additive effect also masked the rate response that was sometimes evident in the single application trials. With the repeat application the overall level of control was improved, particularly by the low rate $(32.5 \mathrm{~g} / \mathrm{ha})$. One reason for this could be the partial recovery of weed populations during the season in the case of a single application. This recovery is reflected in the tuber numbers where there was no significant rate effect, with all rates reducing tuber numbers to about half of the base treatment. The repeat treatments further reduced the tuber numbers to $10-20 \%$ of the base treatment.

Plant counts at regular intervals (only some presented in Tables) showed that in plots not receiving halosulfuron (base treatment only), purple nutsedge populations peaked in January and then declined over the remainder of the season. In the plots treated with halosulfuron, however, nutsedge populations peaked about a month later. This delayed peak, after the phytotoxic effects of halosulfuron had dissipated, tended to lessen the observed rate effect as the season progressed (Table 1). The late season partial recovery of the nutsedge populations indicates that repeat annual applications of halosulfuron will be required to achieve good control of this problem weed. At Matamata, where the purple nutsedge population was high, repeat applications of 32.5 $\mathrm{g} / \mathrm{ha}$ rate reduced the number of plants and tubers considerably more than a single application of halosulfuron (Table 1). Although similar trends are apparent from the results of Te Teko trials (Table 2), which had a much lower weed population, the benefits of repeat treatments over a single application were not as marked as in the Matamata trial.

\section{Crop tolerance trials}

Observations of the maize plants made soon after treatment with halosulfuron showed that within three days of application, the plants began to show symptoms of chlorosis. These comprised a pale green to yellow blotching of the leaves at the point of emergence from the whorl. Within a week after treatment, many of the treated leaves and the whole of the newly emerging leaf became chlorotic. Visual assessments showed that this damage was rate related (Table 3 ) and was quite marked at the highest rate of $260 \mathrm{~g} / \mathrm{ha}$, which is four times the likely commercial rate of $65 \mathrm{~g} / \mathrm{ha}$.

Regular visual assessments suggested that damage to the crop reached maximum levels within 10-14 days after treatment with halosulfuron. Plant height measurements around a fortnight after treatment showed that the chlorosis damage also resulted in significant stunting of the plant, which was quite obvious in plots treated with the 260 $\mathrm{g} / \mathrm{h}$ a rate in all trials. Both the extent of chlorosis and the speed at which it developed varied between trials and seasons and appeared to be related to the rate of crop growth. As the tolerance of maize to halosulfuron comes from the rapid metabolism of the 
herbicide in the plant, a plant that is growing more vigorously will metabolise the herbicide more efficiently and hence suffer less damage as well as overcome the damage more quickly. Dry matter weights of plants in the 1996/97 trial at Rukuhia showed that the stunted plants also weighed less than those in the standard treatment, although the differences were significant only in the case of $260 \mathrm{~g} / \mathrm{ha}$ rate.

\section{TABLE 3: Damage, height and dry matter of maize and grain yield from crop} tolerance trials.

\begin{tabular}{lccccc}
\hline $\begin{array}{l}\text { Herbicide } \\
(\mathrm{g} / \mathrm{ha})\end{array}$ & $\begin{array}{c}\text { Chlorosis } \\
(\%)\end{array}$ & $\begin{array}{c}\text { Height } \\
(\mathrm{cm})\end{array}$ & $\begin{array}{c}\text { Dry wt. } \\
(\mathrm{kg} / \mathrm{ha})\end{array}$ & $\begin{array}{c}\text { Grain } \\
\text { moisture } \\
(\%)\end{array}$ & $\begin{array}{c}\text { Grain } \\
\text { yield } \\
(\mathrm{t} / \mathrm{ha})\end{array}$
\end{tabular}

\begin{tabular}{|c|c|c|c|c|c|c|}
\hline \multicolumn{7}{|c|}{ Gordonton trial $1995 / 96$} \\
\hline Halosulfuron 9.12.95 & $\underline{15.12 .95}$ & $\underline{22.12 .95}$ & $\underline{22.12 .95}$ & $-\mathrm{b}$ & $\underline{8.5 .96}$ & $\underline{8.5 .96}$ \\
\hline acetochlor 2500 & 0 & 0 & 105.8 & - & 23.9 & 10.7 \\
\hline + halosulfuron 65 & 10 & 3 & 95.0 & - & 23.9 & 11.5 \\
\hline + halosulfuron 130 & 15 & 7 & 92.5 & - & 24.0 & 11.3 \\
\hline + halosulfuron 260 & 20 & 8 & 88.3 & - & 23.7 & 11.6 \\
\hline $\operatorname{LSD}(5 \%)$ & 6 & 4 & 5.1 & - & 0.6 & 0.8 \\
\hline \multicolumn{7}{|c|}{ Rukuhia trial 1996/97 } \\
\hline halosulfuron 5.12.96 & $\underline{9.12 .96}$ & $\underline{12.12 .96}$ & $\underline{18.12 .96}$ & $\underline{18.12 .96}$ & $\underline{16.5 .97}$ & $\underline{16.5 .97}$ \\
\hline acetochlor 2500 & 0 & 0 & 78.5 & 689 & 19.7 & 11.1 \\
\hline + halosulfuron 65 & 4 & 2 & 69.3 & 593 & 19.8 & 11.1 \\
\hline + halosulfuron 130 & 5 & 5 & 66.3 & 595 & 19.9 & 10.6 \\
\hline $\begin{array}{l}+ \text { halosulfuron } 260 \\
\text { alachlor } 3400\end{array}$ & 8 & 15 & 64.3 & 561 & 20.0 & 10.5 \\
\hline $\begin{array}{l}\text { + halosulfuron } 130 \\
\text { dimethanamid } 1500\end{array}$ & 5 & 5 & 66.2 & 617 & 19.8 & 11.1 \\
\hline $\begin{array}{l}+ \text { halosulfuron } 130 \\
\text { metolachlor } 3200\end{array}$ & 5 & 5 & 64.8 & 594 & 19.7 & 10.9 \\
\hline $\begin{array}{l}\text { +halosulfuron } 130 \\
\text { pendimethalin } 2000\end{array}$ & 5 & 5 & 66.5 & 613 & 19.8 & 11.0 \\
\hline +halosulfuron 130 & 5 & 5 & 66.0 & 589 & 19.7 & 10.6 \\
\hline $\operatorname{LSD}(5 \%)$ & 3 & 7 & 4.9 & 113 & NS & 0.8 \\
\hline
\end{tabular}

${ }^{a}$ Pre-emergence atrazine $(1.5 \mathrm{~kg} / \mathrm{ha})$ was applied tank mixed with each of the preemergence herbicide treatments in both years, except for metolachlor which was in commercial mixture with terbuthylazine at $1.8 \mathrm{~kg} / \mathrm{ha}$.

${ }^{\mathrm{b}}$ Data not collected in the $1995 / 96$ season.

Further assessments of crop damage showed that within 3-4 weeks after treatment, the proportions of plants showing chlorosis had decreased considerably as new healthy leaves were produced, leaving any chlorotic leaves at the base of a now rapidly growing and apparently healthy plant. A month after treatment the previously damaged plants could only be identified by careful inspection of the old leaves at the base of the plants and any damage appeared insignificant at this stage. The stunting effect also appeared to be temporary suggesting that halosulfuron does not affect all aspects of plant development and overall growth appears to be less affected than the initial plant height. By late January the crop had tasselled and produced silks with no obvious treatment effects remaining. Grain yield and moisture content data showed that there was no yield suppression or delayed development of the crop (which would have been reflected in higher grain moisture content) from any halosulfuron treatment in any of the four trials.

In the 1996/97 Rukuhia trial, halosulfuron was applied after prior use of five different pre-emergence herbicides. None of these pre-emergence herbicides appeared 
to influence the tolerance of maize to halosulfuron (Table 3). This indicates that it would be safe to use halosulfuron after any of the currently registered pre-emergence herbicides. Thus if an infestation of purple nutsedge was found after the crop was established then the choice of the pre-emergence herbicide should have no influence on the decision to use halosulfuron.

Based on the results of these trials, halosulfuron appears to have the potential for selective control of purple nutsedge in maize crops. It caused severe damage to the foliage and significantly reduced the number of plants and ground cover of the weed. Repeat annual applications of halosulfuron would be necessary to reduce the number of tubers to low levels. It may be possible to use lower rates in the second and subsequent seasons. Halosulfuron caused chlorosis symptoms in the treated maize plants within 2 - 3 days after spraying. It also resulted in a general stunting of the crop after about 2 weeks. The plants grew out of all damage symptoms, however, and the final grain yields or the maturity of the crop were not affected.

\section{ACKNOWLEDGEMENTS}

We are grateful to the maize growers who provided trial sites for this research and the agricultural contractors who co-operated in establishing these trials. Judy Mellsop and John Gow assisted with the field work and Dr John Waller performed the statistical analyses. We would also like to acknowledge the financial support of the Foundation for Arable Research, Monsanto New Zealand Limited, Environment BOP, Environment Waikato and the Auckland Regional Council.

\section{REFERENCES}

Allan, H.H., 1940. A handbook of the naturalized flora of New Zealand. DSIR Bulletin No. 83, p. 222, E.V. Paul, Government Printer, Wellington, New Zealand.

Hauser, E.W., 1962. Development of purple nutsedge under field conditions. Weeds 10: $315-321$.

Hawton, D., Howitt, C.J. and Johnson, I.D.G., 1992. A comparision of methods for the control of Cyperus rotundus L. Tropical Pest Management 38: 305-309.

Healy, A.J. and Edgar, E., 1980. Cyperaceae. Pp 189-1990 In: Flora of New Zealand Vol. III Government Printer, Wellington, New Zealand.

Holm, L.G., Plucknett, D.L., Pancho, J.V. and Herberger, J.P., 1977. Cyperus rotundus. Pp 8-24 In: The World's Worst Weeds, University Press of Hawaii, Honolulu, U.S.A.

Rao, J., 1968. Studies on the development of tubers in nutgrass and their starch content at different soil depths. Madras Agric. J. 55: 19-23.

Sanders, P. and Rahman, A., 1995. Control of nutgrass (Cyperus rotundus) in asparagus. Proc. 48th N.Z. Plant Prot. Conf.: 322-326.

Santos, B.M., Bewick, T.A., Staff, W.M. and Shilling, D.G., 1997. Competitive interactions of tomato (Lycopersicon esculentum) and nutsedges (Cyperus spp.). Weed Sci. 45: 229-233.

Suzuki, K., Nawamaki, T., Watanabe, S., Yamamoto, S., Sato, T., Morimoto, K. and Wells, B.H., 1991. NC - 319 - A new herbicde for control of broad-leaved weeds and Cyperus spp. in corn. Proc. Brighton Crop Prot. Conf. - Weeds: 31-37.

Vencill, W.K., Richburg, J.S., Wilcut, J.W. and Hawf, L.R., 1995. Effect of MON 12037 on purple (Cyperus rotundus) and yellow (Cyperus exculentus) nutsedge. Weed Technology 9: 148-152.

Webster, T.M. and Coble, H.D., 1997. Purple nutsedge (Cyperus rotundus) management in corn (Zea mays) and cotton (Gossypium hirsutum) rotations. Weed Technology 11: 543 - 548 . 